\title{
GAMBARAN PERILAKU PENGOBATAN PASIEN TB MDR FASE INTENSIF DI RS DR MOEWARDI SURAKARTA
}

\author{
Farid Setyo Nugroho ${ }^{1}$, Zahroh Shaluhiyah ${ }^{2}$, Sakundarno Adi $^{3}$ \\ ${ }^{1,2,3}$ Fakultas Kesehatan masyarakat, Universitas Diponegoro \\ Email: ${ }^{1}$ faridsetyo25@gmail.com, ${ }^{2}$ shaluhiyah.zahroh@gmail.com, \\ 3adisakundarno@yahoo.com
}

\begin{abstract}
ABSTRAK
Faktor penyebab kekebalan Mycobacterium tuberculose terhadap Obat Anti TB (OAT) adalah perilaku manusia, baik penyedia layanan, pasien, maupun program atau sistem layanan kesehatan yang berakibat terhadap tatalaksana pengobatan pasien TB yang tidak sesuai dengan standar dan mutu yang ditetapkan. Penelitian ini bertujuan untuk mengetahui gambaran perilaku pengobatan pada pasien TB MDR fase intensif di RSDM Surakarta. Penelitian ini menggunakan cross sectional dengan metode gabungan dengan pendekatan kuantitaf dan kualitatif. Metode pengambilan sampling dilakukan secara total sampling yaitu sebanyak 28 responden dan 2 informan. Hasil penelitian menunjukkan bahwa sebanyak 64\% responden tidak patuh dalam menjalankan saran medis, 55\% responden memiliki pengetahuan yang baik tentang TBC, 50\% responden memiliki sikap yang kurang terhadap pengobatan TBC, $75 \%$ responden merasakan efek samping yang banyak, 86\% responden mengeluarkan biaya tambahan selama pengobatan, dan $32 \%$ keluarga responden kurang memberikan dukungan selama pengobatan. Hasil kualitatif menunjukkan bahwa informan menyampaikan bahwa efek samping yang berat menjadi alasan informan menghentikan pengobatan.
\end{abstract}

Kata kunci: TB MDR, Perilaku, Pengobatan, Fase Intensif

\begin{abstract}
The factor that causes Mycobacterium tuberculose immunity to antiTB drugs (OAT) is human behavior, both service providers, patients, and health care programs or systems that result in treatment of TB patients who are not in accordance with the standards and quality established. The purpose of the study was to determine the description of treatment behavior in intensive phase MDR TB patients in RSDM Surakarta. The cross-sectional method was used in the study with a quantitative and qualitative approach. The sampling method was carried out in total sampling as many as 28 respondents and 2 informants. The results showed that as many as $64 \%$ of respondents were not compliant in carrying out medical advice, $55 \%$ of respondents had good knowledge about $\mathrm{TB}, 50 \%$ of respondents had a
\end{abstract}


lack of attitude towards TB treatment, $75 \%$ of respondents felt a lot of side effects, $86 \%$ of respondents paid additional during treatment, and $32 \%$ of respondents' families gave less support during treatment. The qualitative results displayed that the informant said that severe side effects were the reason the informant stopped treatment.

Keywords: MDR TB, Behavior, Treatment, Intensive Phase

\section{PENDAHULUAN}

Secara global menurut World Health Organization (WHO) memperkirakan proporsi kasus baru TB-MDR pada tahun 2013 sebesar 3,5\%, hal ini berarti bahwa sebanyak 480.000 kasus baru TB-MDR telah terjadi di seluruh dunia. Angka kematian akibat TB-MDR di seluruh dunia sebesar 210.00 orang. Angka keberhasilan pengobatan TB-MDR masih rendah, secara global angka keberhasilan pengobatan hanya sebesar $48 \%$ dari target keberhasilan sebesar 85\% (WHO, 2013).

Indonesia berada pada peringkat 8 dari 27 negara yang memilki beban kasus TB-MDR dengan perkiraan penderita sebesar 6.900, yaitu 1,9\% dari kasus baru dan $12 \%$ dari kasus pengobatan ulang. Pada tahun 2013 proporsi kasus baru TBMDR di Indonesia sebesar 1,9\%. Tren kasus TB-MDR di Indonesia terus naik dari tahun ke tahun. Berdasarkan hasil uji laboratorium yang dilakukan, pada tahun 2013 diketahui sebanyak 921 orang terkonfirmasi TB-MDR dengan pasien yang sedang menjalani pengobatan sebanyak 809 orang (WHO, 2014). Masih banyaknya orang yang belum menjalani pengobatan merupakan permasalahan yang besar, karena pasien yang tidak menjalani pengobatan akan meningkatkan resiko kematian dan penularan TB MDR.

Lima provinsi terbanyak yang mengobati TB dengan obat program adalah DKI Jakarta (68.9\%). DI Yogyakarta (67,3\%), Jawa Barat $(56,2 \%)$, Sulawesi Barat $(54,2 \%)$ dan Jawa Tengah (50.4\%). Sedangkan Lima provinsi dengan TB paru tertinggi di Indonesia adalah Jawa Barat (0.7\%), Papua (0.6\%), DKI Jakarta (0.6\%), Gorontalo (0.5\%), Banten $(0.4 \%)$ dan Jawa Tengah $(0.4 \%)$ (Kemenkes RI, 2013).

Angka kesembuhan TB di Jawa Tengah masih sebesar 81,46\%, hal menunjukkan bahwa angka kesembuhan TB di Jawa Tengah masih dibawah target nasional sebesar $85 \%$. Permasalahan kekebalan ganda terhadap OAT juga terjadi di Jawa Tengah, dimana terdapat 59 kasus TB-MDR. Diantaranya adalah di Eks Karesidenan Surakarta sebanayak 21 kasus, Eks Karesidenan Kedu 5 kasus, Eks Karesidenan Semarang 8 kasus, Eks Karesidenan Pati 15 kasus, Eks Karesidenan Pekalongan 2 kasus, dan Eks Karesidenan Banyumas 8 kasus (Dinkes Prov Jateng, 2013).

Provinsi Jawa Tengah memiliki 2 rumah sakit sebagai rujukan penanganan pasien TB-MDR. Salah satu rumah sakit yang menjadi rujukan adalah Rumah Sakit Umum Daerah (RSDM) DR. Moewardi Surakarta. Berdasarkan data yang didapatkan 3 tahun terkahir di RSUD DR. Moewardi Surakarta diketahui sebanyak 269 pasien dengan TB-MDR menjalani program pengobatan TB-MDR, 13\% pasien drop out dan $11 \%$ pasien meninggal. Pasien yang menjalani program pengobatan di RSUD DR. Moewardi Surakarta berasal dari wilayah Jawa Tengah bagian timur dan wilayah Jawa Timur bagian barat, sehingga jumlah yang ditangani cukup banyak.

Faktor penyebab terjadinya resistensi kuman terhadap Obat Anti TB 
(OAT) adalah perilaku manusia, baik penyedia layanan, pasien, maupun program atau sistem layanan kesehatan yang berakibat terhadap tatalaksana pengobatan pasien TB yang tidak sesuai dengan standar dan mutu yang ditetapkan (Kemenkes RI, 2013). Perilaku berobat secara teratur bagi penderita TB tetap menjadi permasalahan untuk mencapai angka kesembuhan yang tinggi. Tingginya angka putus obat mengakibatkan tingginya kasus TB MDR dan akan membutuhkan biaya yang lebih besar serta bertambah lamanya pengobatan.

\section{METODE PENELITIAN}

\section{Desain Penelitian}

Jenis penelitian ini adalah deskriptif dengan pendekatan cross sectional dengan menggunakan metode gabungan (mixed methods) dengan pendekatan kuantitatif dan kualitatif. Pendekatan kualitatif dilakukan untuk mengetahui secara mendalam alasan putusnya pengobatan pasien TB MDR.

\section{Populasi, Sampel dan Informan}

Populasi pada penelitian ini adalah seluruh pasien yang terdiagnosis sebagai pasien TB MDR fase intensif di RSDM Surakarta pada bulan maret 2018. Sampel dalam penelitian ini adalah seluruh pasien TB MDR fase intensif di RSDM Surakarta sebanyak 28 responden. Informan yang diambil dalam penelitian ini adalah 2 orang pasien TB MDR yang telah putus pengobatan dan belum bersedia untuk melanjutkan pengobatan kembali.

\section{HASIL DAN PEMBAHASAN}

\section{Kuantitatif}

Data distribusi frekuensi jenis kelamin dapat dilihat pada Tabel 1.
Tabel 1. Distribusi frekuensi jenis kelamin

\begin{tabular}{ccc}
\hline Jenis kelamin & n & \% \\
\hline Laki-laki & 16 & 57 \\
Perempuan & 12 & 43 \\
\hline Total & 28 & 100 \\
\hline erdasarkan & Tabel & 1 \\
\end{tabular}

bahwa sebagian besar (57\%) responden berjenis kelamin laki-laki.

Tabel 2. Distribusi frekuensi usia responden

\begin{tabular}{cll}
\hline Usia & n & \% \\
\hline$<39$ tahun & 16 & 57 \\
$\geq 39$ tahun & 12 & 43 \\
\hline Total & 28 & 100 \\
\hline
\end{tabular}

Berdasarkan Tabel 2 diketahui bahwa sebagian besar (57\%) responden memiliki usia dibawah 39 tahun.

Tabel 3. Distribusi frekuensi tingkat pendidikan

\begin{tabular}{lll}
\hline Pendidikan & n & \% \\
\hline Rendah & 11 & 39 \\
Tinggi & 17 & 61 \\
\hline Total & 28 & 100 \\
\hline
\end{tabular}

Tabel 3 menunjukkan bahwa responden sebagian besar responden memiliki pendidikan tinggi (SMA - PT) sebesar 17 (61\%). Responden dengan pendidikan rendah (SD - SMP) sebesar 11 (39\%).

Tabel 4. Distribusi frekuensi kepatuhan dalam menjalankan saran medis

\begin{tabular}{lll}
\hline Kepatuhan & $\mathbf{n}$ & $\mathbf{\%}$ \\
\hline Patuh & 10 & 36 \\
Tidak patuh & 18 & 64 \\
\hline Total & 28 & 100 \\
\hline
\end{tabular}

Berdasarkan Tabel 4 menunjukkan bahwa sebesar 18 (64\%) responden tidak patuh dalam menjalankan saran medis. 
Tabel 5. Distribusi frekuensi tingkat pengetahuan responden tentang penyakit

TBC

\begin{tabular}{lll}
\hline Tingkat Pengetahuan & n & \% \\
\hline Kurang & 13 & 45 \\
Baik & 15 & 55 \\
\hline Total & 28 & 100 \\
\hline
\end{tabular}

Berdasarkan Tabel 5 diketahui bahwa sebagian besar responden (55\%) memiliki pengetahuan yang baik tentang penyakit TBC.

Tabel 6. Distribusi frekuensi sikap responden terhadap pengobatan TB MDR

\begin{tabular}{lll}
\hline Sikap & n & \% \\
\hline Kurang & 14 & 50 \\
Baik & 14 & 50 \\
\hline Total & 28 & 100 \\
\hline
\end{tabular}

Berdasarkan Tabel 6 diketahui bahwa jumlah responden yang memiliki sikap yang kurang terhadap pengobatan TBC sebesar 14 (50\%) responden.

Tabel 7. Distribusi frekuensi efek samping obat yang dirasakan responden

\begin{tabular}{lll}
\hline Efek Samping & n & \% \\
\hline Banyak & 21 & 75 \\
Sedikit & 7 & 25 \\
\hline Total & 28 & 100 \\
\hline
\end{tabular}

Berdasarkan Tabel 7 diketahui bahwa sebagian besar responden (75\%) mengalami efek samping yang banyak. Efek samping yang banyak dirasakan oleh responden adalah berupa mual dan muntah.

Tabel 8. Distribusi frekuensi biaya tambahan responden

\begin{tabular}{lll}
\hline Biaya Tambahan & n & \% \\
\hline Ada & 24 & 75 \\
Tidak Ada & 4 & 25 \\
\hline Total & 28 & 100 \\
\hline
\end{tabular}

\footnotetext{
Berdasarkan Tabel 8 diketahui bahwa sebesar $75 \%$ responden mengeluarkan biaya tambahan selama menjalani pengobatan TB MDR.
}

Tabel 9. Distribusi frekuensi dukungan keluarga responden selama menjalani pengobatan

\begin{tabular}{lll}
\hline Dukungan Keluarga & n & \% \\
\hline Mendukung & 19 & 68 \\
Kurang & 9 & 32 \\
\hline Total & 28 & 100 \\
\hline
\end{tabular}

Berdasarkan Tabel 9 diketahui bahwa sebesar 32\% responden kurang mendapatkan dukungan keluarga selama menjalani pengobatan TB MDR.

\section{Kualitatif}

Hasil wawancara mendalam dengan 2 orang informan yang telah putus pengobatan dan di triangulasikan dengan key person (peer educator) didapatkan hasil sebagai berikut:

Informan 1 usia 68 tahun:

"begini mas, berhubung waktu saya itu minum obat dari jebres (RSDM), itu kan dari puskesmas dikirim dari jebres, berhubung kondisi saya ini tidak kuat sama sekali mas, saya itu seumpama saya cocok yang minum obat, dah tidak ada sajalah (meninggal), badan saya sudah habis (kurus), kalau minum obat saya itu, boro-boro kok bisa berdiri seperti saat ini, rasanya sakit kepala, mual, muntah, pokoknya sudah tidak karu-karuan rasanya

Berdasarkan hasil wawancara mendalam dapat diketahui bahwa alasan informan putus pengobatan adalah karena tidak kuat dengan efek samping yang dirasakan. Hal ini diperkuat dengan pernyataan dari key person yaitu peer educator sebagai berikut:

"tidak ada mas sepertinya, kalau informan 1 menurut saya ya karena usia juga sudah tua jadi tidak kuat untuk menahan efek sampingnya, kalau suntiknya masih bisa kuat mas, tapi kalau untuk minum obatnya sepertinya itu jadi alasan atau hambatan utama kenapa informan 1 putus mas"

Informan 2, usia 52 tahun: 
"ya obatnya itu, nggliyeng, begitu minum obat sampai nanti malam mau sholat itu tidak kuat, baru sadar jam 2 dini hari minta istri untuk menghangatkan bubur kacang ijo itu pun saya hisap-hisap, ya cuma cairan gitu terus berat badan turun sampai $30 \mathrm{~kg}$....

Berdasarkan hasil wawancara mendalam, informan 2 menyatakan bahwa alasan putus pengobatan TB MDR karena meraskan efek samping obat berupa sakit kepala, tidak sadarkan diri sampai jam 2 dini hari dan tidak mempunyai nafsu makan sehingga membuat berat badan informan turun menjadi $30 \mathrm{~kg}$. Hal ini diperkuat dengan pernyataan dari key person yaitu peer educator sebagai berikut:

"kalau menurut saya, alasannya itu efek sampingnya mas, efek sampingnya memang kalau orangnya tidak kuat, bisa putus dijalan, karena efek sampingya terlalu banyak, kalau saya lihat memang kendalanya itu makannya, obatnya sangat mempengaruhi terhadap lambung, jadi makan itu terasa tidak enak semua, itu mas. ,

\section{Pembahasan Kuantitatif Jenis Kelamin}

Sebagian besar responden berjenis kelamin laki-laki (57 \%) dibandingkan dengan responden dengan jenis kelamin perempuan $(43 \%)$. Berdasarkan hasil tersebut dapat dikemukakan bahwa lakilaki lebih rentan terkena penyakit TB MDR. Kerentanan ini kemungkinan disebabkan oleh beban kerja, istirahat yang kurang, mobilisasi yang tinggi, serta gaya hidup yang tidak sehat di antaranya adalah merokok dan minum alkohol. Perilaku-perilaku tersebut dapat menjadi faktor risiko yang dapat menurunkan kekebalan tubuh sehingga rentan terkena TB MDR. Jenis kelamin merupakan sebuah konsep kultural yang berusaha membuat perbedaan (distincition) pada karakteristik emosional, perilaku, perasaan, dan perilaku antara laki-laki dan perempuan dalam sebuah masyarakat. Hasil penelitian lain menunjukkan bahwa laki-laki lebih mudah terkena penyakit TB MDR, hal ini dikarenakan beban kerja, istirahat yang tidak teratur, serta gaya hidup tidak sehat diantaranya adalah merokok dan minum alkohol (Kondoy dkk., 2014).

\section{Usia}

Sebagian besar responden $(57 \%)$ termasuk dalam kategori usia kurang dari 39 tahun. Pada ini seseorang cenderung memiliki mobilitas yang tinggi sehingga memungkinkan untuk terpapar oleh kuman TBC lebih besar. Menurut Notoatmodjo umur adalah lamanya hidup yang dihitung sejak manusia dilahirkan. Bertambahnya umur manusia berarti semakin meningkat pula kemampuan menanggapi permasalahan. Bertambahnya umur maka semakin dewasa pula individu untuk melakukan penyesuaian perilaku terhadap lingkungan (Notoatmodjo, 2010). Usia yang semakin tua akan membuat perilaku berobat semakin baik, hal ini dikarenakan usia tua tidak memiliki banyak aktivitas pekerjaan sehingga dapat mengikuti pengobatan secara teratur (Rusmani, 2002). Hasil penelitian ini sejalan dengan beberapa hasil penelitian lain yang menyatakan bahwa umur tidak berpengaruh terhadap perilaku seseorang, hal ini karena adanya faktor perantara seperti sikap seseorang dan faktor lainnya yang dapat mempengaruhi keinginan seseorang (Bart, 1994). Kesakitan TBC paling banyak biasanya pada usia dewasa. Penyakit TBC sebagian besar terjadi pada orang dewasa yang telah mendapatkan infeksi primer pada saat kecil dan tidak ditangani dengan baik. Kelompok usia dewasa yang selanjutnya diikuti oleh kelompok usia tua merupakan kelompok yang paling sering terinfeksi TBC di 
Amerika Serikat pada tahun 2008 (CDC, 2009).

\section{Pendidikan}

Sebagian besar responden $(61 \%)$ memiliki pendidikan tinggi. Menurut Notoatmodjo (2010), semakin tinggi pendidikan seseorang maka semakin banyak bahan, materi atau pengetahuan seseorang. Pendidikan diperlukan untuk memperoleh pengetahuan misalnya halhal yang mendukung kesehatan, sehingga dapat meningkatkan kesehatan dan kualitas kehidupan. Lebih banyaknya jumlah penderita pada kategori pendidikkan tinggi kemungkinan dapat disebabkan kurangnya penderita dalam menerima sebuah informasi kesehatan dibandingkan dengan penderita dengan pendidikan rendah. Tingkat pendidikan formal merupakan landasan seseorang dalam berbuat sesuatu, membuat lebih mengerti dan memahami sesuatu, atau menerima dan menolak sesuatu. Tingkat pendidikan formal juga memungkinkan perbedaan pengetahuan dan pengambilan keputusan. Berdasarkan penelitian ini sebagian besar pasien yang menderita $\mathrm{TB}$ MDR adalah pasien dengan pendidikan tinggi hal ini membuktikan bahwa tingkat pendidikan seseorang tidak mempengaruhi terhadap status kesehatan.

\section{Kepatuhan Dalam Menjalankan Saran Medis}

Dalam penelitian ini Responden dikatakan patuh apabila melaksanakan anjuran dari petugas kesehatan seperti minum obat secara teratur, tidak merokok, minum obat setiap hari, mengkonsumsi makanan atau minuman bergizi, tidur (istirahat) teratur, olahraga teratur, dan kontrol secara teratur. Responden dikatakan tidak patuh apabila tidak melakukan semua anjuran petugas kesehatan. Sedangkan hasil penelitian menunjukkan bahwa sebesar 17 (61\%) responden tidak patuh dalam menjalankan saran medis berupa olahraga secara teratur, sedangkan sebesar $8 \quad(29 \%)$ responden tidak patuh dalam menjalankan saran medis berupa tidur secara teratur. Selama penderita menjalani pengobatan TBC, terdapat kemungkinan adanya ketidakpatuhan penderita TBC dalam melaksanakan instruksi medis. Hasil penelitian menunjukkan $64 \%$ responden tidak patuh dalam pengobatan TB MDR. Berdasarkan teori L. Green terdapat tiga faktor yang mempunyai pengaruh dalam membentuk perilaku yaitu: 1) Faktor predisposisi berupa pengetahuan, sikap, dan karaktersitik responden 2) Faktor pendorong berupa sikap petugas kesehatan, 3) Faktor pendukung berupa ketersediaan fasilitas prasarana dan sarana kesehatan (Green, 2000). Kepatuhan penderita berdasarkan keterpaksaan atau tidak paham mengenai pentingnya perilaku, dapat diikuti oleh kepatuhan yang berbeda, diantaranya kepatuhan demi menjaga hubungan yang baik dengan petugas kesehatan atau panutan yang menganjurkan perubahan tersebut (change agent) (Notoatmodjo, 2010).

\section{Pengetahuan Tentang Penyakit TBC}

Sebanyak 55\% responden dalam penelitian ini memiliki pengetahuan yang baik tentang TBC. Responden dengan pengetahuan yang baik seharusnya lebih memahami penyakit TB MDR yang diderita. Tingkat pengetahuan yang baik seharusnya mempermudah penderita untuk menjalani pengobatan TB MDR. Berdasarkan hasil penelitian, pertanyaan yang paling banyak di jawab salah oleh responden adalah pernyataan "TBC dapat disebabkan oleh kurang makanan bergizi”, dimana sebesar $23(82 \%)$ responden tidak tepat dalam menjawab pernyataan tersebut. Hal ini menunjukkan bahwa mayoritas responden mempunyai anggapan kurangnya konsumsi makanan bergizi dapat menyebabkan penyakit TBC. Pengetahuan juga dapat menyebabkan 
penderita untuk tidak mematuhi instruksi atau anjuran pengobatan dikarenakan kesalahpahamannya terhadap penyakit TB MDR yang diberikan (Syukra, 2015).

\section{Sikap Terhadap Pengobatan TB MDR}

Sebanyak $50 \%$ responden dalam penelitian ini memiliki sikap yang kurang dalam pengobatan TB MDR. sikap merupakan salah satu komponen perilaku, dimana perilaku akan mempengaruhi status kesehatan seseorang (Notoadmodjo, 2010). Penentuan sikap, keyakinan, dan emosi memiliki peranan penting dalam terbentuknya perilaku. Berdasarkan keterangan responden juga diketahui bahwa sebanyak $25 \%$ responden menyatakan bahwa tidak setuju mengikuti pengobatan TB MDR selama 21 bulan. Jumlah obat yang banyak dan waktu yang lama dalam proses pengobatan TB MDR turut membentuk sikap yang kurang baik pada penderita TB MDR. Terdapatnya efek samping yang berat akan membentuk sikap terhadap proses pengobatan sehingga sikap dapat menentukan terciptanya sebuah perilaku kesehatan dan terwujudnya kualitas kesehatan individu atau masyarakat. Seperti halnya pengetahuan, sikap juga memiliki hierarki berdasarkan intensitasnya sebagai berikut: bersedia menerima rangsangan (stimulus) yang diberikan (objek), menyampaikan jawaban atau umpan balik terhadap pertanyaan atau objek yang dihadapi, menyampaikan nilai yang positif terhadap suatu objek atau rangsangan, dengan maksud membahasnya dengan orang lain, bahkan mengajak, mempengaruhi serta menganjurkan orang lain untuk memberikan respon (tanggapan), sikap yang paling tinggi tingkatnya adalah memilki tanggung jawab terhadap apa yang menjadi keyakinan (Notoadmodjo, 2003).

\section{Efek Samping Obat}

Sebanyak $75 \%$ responden dalam penelitian ini menyatakan mengalami efek samping yang banyak. Semua responden menyatakan merasakan efek samping setiap hari setelah menelan obat. Efek samping yang paling banyak dirasakan oleh responden adalah mual dan muntah. Adanya efek samping obat merupakan salah satu penyebab terjadinya kegagalan dalam pengobatan TB MDR. Hal ini dapat diatasi dengan memberikan informasi mengenai cara mengatasi efek samping, sehingga penderita akan mengetahui lebih dahulu tentang efek samping obat dan tidak cemas apabila pada saat menelan obat terjadi efek samping obat (Suryatenggara, 1990). Efek samping yang ringan dari obat sebenarnya dapat ditangani sehingga penderita dapat melanjutkan minum obat tanpa menghentikannya.

\section{Biaya Tambahan yang Dikeluarkan Selama Pengobatan}

Sebagian besar responden $(75 \%)$ menyatakan mengeluarkan biaya tambahan selama menjalani pengobatan TB MDR. mayoritas responden mengeluarkan biaya untuk membeli bensin dan membayar parkir. Biaya pengganti transportasi itu sebenarnya sudah diberikan oleh RSDM Surakarta yaitu sebesar 700.000 rupiah setiap bulannya. Pemberian uang pengganti transport ini dapat memotivasi responden untuk rajin dalam menjalani pengobatan TB MDR. Penelitian lain yang dilakukan oleh Pandit dan Choudhary di distrik Anand, India memberikan hasil yang serupa dengan penelitian ini. Beberapa faktor risiko ketidakpatuhan berobat tradisional seperti faktor sosio-demografi, waktu lama, jarak perjalanan ke fasilitas kesehatan, serta biaya pemeriksaan dan pengobatan bukan lagi merupakan kendala utama yang dikeluhkan pasien untuk berobat (Pandit \& Choudary, 2006). 


\section{Dukungan Keluarga}

Sebanyak 32 responden menyatakan kurang mendapatkan dukungan keluarga selama menjalani pengobatan. Dukungan keluarga yang positif adalah berperan serta secara penuh pada pengobatan penderita seperti; pengaturan menu makan dan minum, istrahat, perawatan kebersihan diri, pengambilan obat serta mampu memotivasi penderita bila mengalami efek samping yang berat (Limbu \& Marni, 2007). Dukungan keluarga juga dapat berupa mengantar untuk melakukan pemeriksaan di puskesmas dan di rumah sakit, dokter atau petugas kesehatan. Selain sebagai pihak yang selalu mendukung untuk kesembuhan keluarga juga berperan sebagai Pengawas Minum Obat (PMO) yang mempunyai tugas untuk mengawasi dan mengingatkan secara terus menerus kepada penderita supaya menelan obatnya secara teratur dan tepat waktu sesuai dengan anjuran atau instruksi dari petugas kesehatan. Keuntungan keluarga sebagai pengawas menelan obat adalah tempat tinggalnya yang satu rumah dengan penderita sehingga pemantauannya lebih optimal. Menurut Friedman (1998) dukungan keluarga merupakan sikap dan penerimaan keluarga terhadap penderita yang sedang sakit. Keluarga berperan sebagai sistem pendukung bagi anggota keluarga yang sakit. Anggota keluarga yang sakit memandang bahwa orang yang memberikan dukungan, selalu siap memberikan pertolongan dan bantuan kapan pun diperlukan (Friedman, 1988).

\section{Pembahasan Kualitatif}

Berdasarkan wawancara mendalam yang dilakukan terhadap 2 orang informan, diketahui bahwa informan 1 menyatakan tidak bersedia (Drop Out) dari pengobatan TB MDR karena merasakan efek samping yang berat. Terdapatnya efek samping yang berat ini menyebabkan informan $\mathrm{P}$ tidak bersedia untuk melanjutkan pengobatan TB MDR, sehingga informan 1 memutuskan untuk menghentikan pengobatan TB MDR. Informan 2 juga menyatakan bahwa tidak kuat menahan efek samping yang dirasakan, sehingga informan 2 pun juga memutuskan untuk menghentikan (drop out). Berdasarkan keterangan Informan 1 dan informan 2 meskipun menghentikan pengobatan TB MDR akan tetapi kedua informan masih berkeinginan untuk sembuh, sehingga kedua informan mencari pengobatan alternatif. Informan 1 mencari pengobatan alternatif berupa meminum obat herbal khusus paru, obat ini rajin dikonsumsi oleh informan 1 dan informan 1 menyatakan bahwa terdapat perkembangan yang lebih baik setelah meminum obat herbal. Sedangkan informan 2 menceritakan bahwa pengobatan alternatif yang diikuti adalah dengan berobat pada dokter spesialis paru. Informan 2 juga menceritakan bahwa biaya pengobatan yang diikuti nya di dokter spesialis paru mengeluarkan biaya yang besar yaitu total biaya yang telah dihabiskan mencapai 50 juta. Walaupun biaya yang dkeluarkan mahal, informan 2 tetap menyatakan ingin melanjutkan pengobatan pada dokter spesialis paru tersebut. Hal ini dikarenakan informan 2 tidak mengalami efek samping selama menjalani pengobatan alternatif pada dokter spesialis paru tersebut. Berdasarkan keterangan responden juga diketahui bahwa sebanyak $25 \%$ responden menyatakan bahwa tidak setuju mengikuti pengobatan TB MDR selama 21 bulan. Jumlah obat yang banyak dan waktu yang lama dalam proses pengobatan TB MDR turut membentuk sikap yang kurang baik pada penderita TB MDR. Terdapatnya efek samping yang berat akan membentuk sikap terhadap proses pengobatan sehingga sikap dapat menentukan terciptanya sebuah perilaku kesehatan dan terwujudnya kualitas kesehatan individu atau masyarakat. Seperti halnya 
pengetahuan, sikap juga memiliki hierarki berdasarkan intensitasnya sebagai berikut: bersedia menerima rangsangan (stimulus) yang diberikan (objek), menyampaikan jawaban atau umpan balik terhadap pertanyaan atau objek yang dihadapi, menyampaikan nilai yang positif terhadap suatu objek atau rangsangan, dengan maksud membahasnya dengan orang lain, bahkan mengajak, mempengaruhi serta menganjurkan orang lain untuk memberikan respon (tanggapan), sikap yang paling tinggi tingkatnya adalah memilki tanggung jawab terhadap apa yang menjadi keyakinan (Notoadmodjo, 2003).

\section{KESIMPULAN}

1. Berdasarkan karakteristik jenis kelamin pasien TB MDR fase intensif di RSDM Surakarta lebih banyak berjenis kelamin laki-laki.

2. Berdasarkan karakteristik usia pasien TB MDR fase intensif di RSDM Surakarta lebih banyak pada usia 39 tahun atau termasuk dalam kategori usia sangat produktif.

3. Berdasarkan karakteristik tingkat pendidikan pasien TB MDR fase intensif di RSDM Surakarta lebih banyak memiliki pendidikan tinggi.

4. Pasien TB MDR fase intensif di RSDM Surakarta lebih banyak yang belum menjalankan saran medis pada saat mengikuti pengobatan TB MDR.

5. Pasien TB MDR fase intensif di RSDM Surakarta lebih banyak yang memiliki pengetahuan yang bagus tentang penyakit TBC.

6. Pasien TB MDR fase intensif di RSDM Surakarta memiliki sikap yang kurang terhadap pengobatan TB MDR.

7. Pasien TB MDR fase intensif di RSDM Surakarta banyak yang mengalami efek samping dalam jumlah yang banyak dan efek samping yang sering dirasakan adalah mual dan muntah.

8. Pasien TB MDR fase intensif di RSDM Surakarta banyak yang mengeluarkan biaya tambahan selama menjalani pengobatan

9. Pasien TB MDR fase intensif di RSDM Surakarta banyak yang mendapatkan dukungan keluarga selama menjalani pengobatan

10. Faktor efek samping obat yang besar menyebabkan pasien TB MDR putus dalam menjalani pengobatan TB MDR

\section{DAFTAR PUSTAKA}

Bart, S. (1994). Psikologi Kesehatan. PT. Gramedia Widiasarna Indonesia : Jakarta.

CDC. (2009). Reported Tuberculosis in the United States, 2008. U.S. Department of Health and Human Services. Atlanta, GA.

Dinas Kesehatan Provinsi Jawa Tengah. (2013). Buku Saku Kesehatan Tri Wulan 3 tahun 2013. Semarang.

Friedman. (1998). Keperawatan Keluarga: Teori dan Praktek. EGC. Jakarta. 
Kementrian Kesehatan RI. (2013). Pedoman Nasional Pelayanan Kedokteran Tata Laksana Tuberkulosis Tahun 2013. Jakarta.

Kementrian Kesehatan RI. (2013). Riset Kesehatan Dasar 2013. Jakarta.

Green, L.W., Kreuter, M.W., Deeds, S.G., Partridge, K.B., \& Bartlett, E. (2000). Health Education Planning: a Diagnosyic Approach. Mayfield Publishing Company. Palo Alto, California.

Limbu, R., \& Marni. (2007). Peran keluarga sebagai pengawas minum obat (PMO) dalam mendukung proses pengobatan penderita tb parudi wilayah kerja puskesmas baumata kecamatan taebenu kabupaten kupang. Diakses dari www.artikel31tuberkulosis.com.doc.pdf pada tanggal 9 Febuari 2016.

Notoatmodjo S. (2003). Pendidikan dan Perilaku Kesehatan. Rineka Cipta. Jakarta.

Notoatmodjo S. (2010). Ilmu Perilaku Kesehatan. Rineka Cipta. Jakarta.

Notoatmojo, S. (2010). Metodologi Penelitian Kesehatan. Rineka Cipta. Jakarta.

Pandit, N., \& Choudary, S.K., (2006). A Study of Treatment Compliance in Direct Observe Therapy for Tuberculosis. Indian Journal of Community Medicine. $31: 4$

Kondoy, P.P.H., Rombot, D.V., Palandeng, H.M.F., \& Pakasi, T.A. (2014). FaktorFaktor Yang Berhubungan Dengan Kepatuhan Berobat Pasien Tuberkulosis Paru di Lima Puskesmas di Kota Manado. Jurnal Kedokteran Komunitas Tropik. Vol II No 1

Rusmani, A. (2002). Kepatuhan Berobat Penderita TB Paru Di Rumah Sakit UmumDaerah (RSUD) Dr. Doris Sylvanus Kota Palangkaraya Propinsi Kalimantan Tengah. Tesis Pascasarjana UGM. Yogyakarta.

Suryatenggara, W. (1990). Pengobatan TB paru, Cermin Dunia Kedokteran. 63:23-8.

Syukra, A. (2015). Buku Ajar Sosiologi Kesehatan. Deepublish. Yogyakarta. 
Jurnal Kesehatan. ISSN 1979-7621 (Print). ISSN 2620-7761 (Online). Vol. 11. No. 1. Juni 2018

World Health Organization. (2013). Global Tb Report. Geneva.

World Health Organization. (2014). Global Tb Report . Geneva. 